\title{
Heuristic forest planning model for optimizing timber production and carbon sequestration in teak plantations
}

\author{
María Alejandra Quintero- \\ Méndez ${ }^{(1)}$, Mauricio Jerez-Rico ${ }^{(2)}$
}

We developed a forest planning model integrating two operational scales (single-stand and forest levels) for the optimization of timber production and carbon sequestration in forest teak (Tectona grandis L. f.) plantations. At the stand level, growth and yield simulations using a heuristic thinning optimizer provided a set of near-optimal thinning regimes for individual stands differing on initial spacing and site quality, given biological, silvicultural, and financial constraints. The set of near-optimal thinning regimes obtained were then used as input of the forest-level model, which generated optimal harvest plans for the whole plantation by simultaneously maximizing the net present value of merchantable wood and carbon sequestration. The net amount of carbon captured by the biomass and the emissions produced by decomposition of woody debris and timber products after harvest were estimated. The growth and yield model was based on a system of differential equations incorporating heuristics (genetic algorithms) to optimize age and intensity of thinnings. The full model can handle the optimization of harvest schedules for projects up to 10,000 ha and 200 stands and was tested on a validation dataset including teak plantations from Venezuela and other Latin American countries. Results indicated that regimes favoring carbon sequestration reduce the benefits of timber production, and equal profitability of carbon sequestration and timber production was obtained for carbon prices over $40 \$ U \mathrm{U} \mathrm{Gg}^{-1}$. Sensitivity analysis showed that the proposed model is sensible to variation in growth rates, carbon and timber prices, and production quotas, and barely sensible to harvest and transport costs. The developed model has a modular structure that allows its calibration to incorporate data from a wide range of management regimes for teak and other forest species.

Keywords: Forest Planning, Harvest Scheduling, Optimization, Heuristics, Carbon Sequestration, Tectona grandis

ned teak logging. Yet, the demand for teak timber is currently increasing, driven by India and China markets. This has led to the development of many teak plantation projects in Asia, Africa, and Latin America (Keogh 2013). By 2010, Latin America had almost 250,000 ha of teak, $80 \%$ of them less than 20 years-old.

Despite its long history as a planted species, reliable information regarding growth and productivity of teak is lacking, and gaps still exist regarding short rotations, growth dynamics and thinning regimes
(1) Escuela de Ingeniería Forestal, Facultad de Ciencias Forestales y Ambientales. Universidad de Los Andes, Mérida 5101 (Venezuela); (2) Centro de Estudios Forestales y Ambientales de Postgrado, Facultad de Ciencias Forestales y Ambientales. Universidad de Los Andes, Mérida 5101 (Venezuela)

@ María Alejandra Quintero-Méndez (mariaalejandraq@gmail.com)

Received: Jun 05, 2015 - Accepted: Oct 30, 2016

Citation: Quintero-Méndez MA, Jerez-Rico M (2017). Heuristic forest planning model for optimizing timber production and carbon sequestration in teak plantations. iForest 10: 430439. - doi: 10.3832/ifor1733-009 [online 2017-03-24]

Communicated by: Giorgio Matteucci
(Fonseca 2004, Pérez 2005). Most research has focused on the optimization of single stand management schedules based on field trials and permanent plots. More recently, growth and yield simulation models were developed to assess the effect of various management options in teak by integrating data from several studies (Bermejo et al. 2004, Jayaraman \& Rugmini 2008, Quintero et al. 2012, Jerez et al. 2015). Nonetheless, forest planning aimed at optimizing management for timber production and carbon sequestration in multiple stands of teak plantations has not been published yet. Forest planning consists in the selection of the best management option to achieve one or several objectives, including biological, ecological, economic, social, and environmental variables. Several techniques are used to develop optimization models and find efficient solutions to forest planning problems, like mathematical programming (e.g., Linear, Integer, Goal, and Dynamic programming). The large number of variables and constraints involved, the existence of non-linear relationships between variables, and the need to simultaneously optimize for different objectives often make the optimization of 
models an arduous task. In this case, heuristic techniques can be applied as they can handle the model complexity more efficiently (Bettinger \& Chung 2004, Pukkala \& Kurttila 2005, Liu et al. 2006). Among these techniques, Simulated Annealing, Genetic Algorithms, Tabu Search, Threshold Accepting, and Ant Colony Algorithms were successfully applied in forest planning (Pukkala \& Kurttila 2005, Liu et al. 2006, Zeng et al. 2007, Zhu \& Bettinger 2008, Quintero et al. 2011).

Different algorithms use different strategies for seeking the optimal solution through the solution space and various criteria allow to evaluate the quality of the solutions obtained. The maximization of profitability and monetary benefits is usually the optimal solution in industrial forest plantations. However, optimizing for carbon sequestration has lately become a major goal of many forest planning models, due to the significant role of forests in the reduction of atmospheric $\mathrm{CO}_{2}$ and climate change mitigation. The adoption of the Kyoto protocol and the creation of carbon markets stimulated the scientific community to focus on the assessment of the $\mathrm{CO}_{2}$ amount stored by forest ecosystems, thus bringing this issue to the attention of forest managers. Indeed, carbon uptake is currently considered a new goal of silvicultural management (Pérez et al. 2007).

Many forest planning models that incorporate carbon sequestration as optimization criteria have been reported in the literature (Hoen \& Solberg 1994, Diaz-Balteiro \& Romero 2003, Backéus et al. 2005, DíazBalteiro \& Rodriguez 2006, Pohjola \& Valsta 2007, Keles \& Baskent 2007, Baskent et al. 2008, Bravo et al. 2008, Raymer et al. 2009, Cao et al. 2010). In addition, several models quantifying carbon stored in teak trees have been developed (Cubero \& Ro- jas 1999, Kraenzel et al. 2003, Gera et al. 2011). However, to our best knowledge, no models have been developed for optimizing timber production and carbon sequestration in teak plantations.

The aim of this work was to optimize management plans of multiple-stand teak plantations by developing a heuristic model which simultaneously maximizes financial benefits from timber production and carbon sequestration.

\section{Material and methods}

\section{Model structure}

The model simulates a teak plantation project comprising many stands differing in age, site quality, and initial spacing. Time of thinning and final harvest for each stand depend on the trade-off between wood production and carbon storage to maximize financial benefits for the project over a planning period of 40 years. Two optimization models working at different planning levels were developed. The first one (sub-model 1) operates at the stand level, and provides a set of "best thinning schedules" for each stand, assuming a fixed final harvest after 30 years. The second model (sub-model 2) operates at the forest level, by choosing for each stand the "best schedules" that maximize financial gains for the whole project, taking into account both carbon and timber goals subject to various constraints. Although the rotation age initially assigned to all stand is 30 years, the forest-level sub-model can modify the optimal harvest age of each stand (i.e., stands could be clear-cut before or after age 30). Single-stand development is simulated by using a yield and growth model, while a second module calculates the carbon budget, comprising storage and emissions (Fig. 1).
Fig. 1 - Basic structure of the forest planning model.

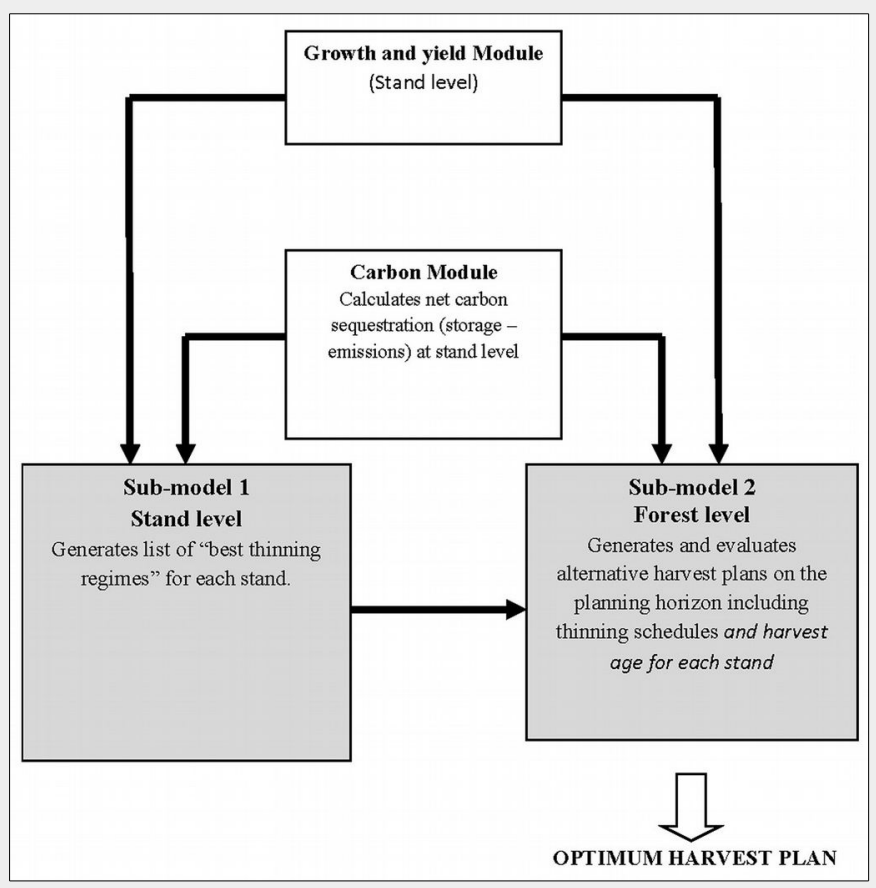

Stand-level optimizer (sub-model 1)

Sub-model 1 generates a set of thinning regimes for each stand with different initial spacing and site quality, and selects a subset of eight "best" thinning schedules, including the "no thinning" option. The objective function maximizes the financial gain, considering at the same time the merchantable timber production and the carbon sequestration in terms of Net Present Value (NPV, in US\$). For each stand, several simulations are done taking into account the desired number of thinnings. The best schedules for each stand are the inputs for sub-model 2.

\section{Forest-level optimizer (sub-model 2)}

Sub-model 2 searches for the optimum harvest schedule (Maximum NPV) for the entire plantation, indicating which stands to thin or harvest each year, and considering both timber production and carbon sequestration. The objective function takes into account the incomes from timber and carbon capture, the cost of planting, maintenance, and transport of timber products. Constraints include a yearly timber production goal varying from year to year. In order to consider the additional costs due to spreading of harvest activities (moving personnel and machinery across the planted area), a spatial index seeks for minimizing the displacement of equipment within the plantation, and assumes no spatial adjacency constraints.

\section{Growth and yield model}

A whole-stand growth and yield model based on differential equations simulates the stand production by projecting stand variables such as basal area, stand density, average diameter, height, and volume for various combinations of site quality, initial spacing, and thinning regime. Basal area growth is calculated as (eqn. 1):

$$
G_{t}=G_{p}\left[1-e^{-k\left(t-t_{o}\right)}\right]^{1 /(1-m)}
$$

where $G_{t}$ is the stand basal area at time $t$ $\left(\mathrm{m}^{2} \mathrm{ha}^{-1}\right), G_{\mathrm{p}}$ is the maximum basal area supported by a given site $\left(\mathrm{m}^{2} \mathrm{ha}^{-1}\right), t_{0}$ is the initial time for running the simulations (yrs), $k$ and $m$ are parameters related to growth rate and scale.

\section{Simulation data set}

Top height growth was derived from a site index (base age 16) family of anamorphic curves derived from the SchumacherHall model (Jerez et al. 2011). Stand density was modeled using a simple negative exponential model to account for density-dependent mortality, and a random function that depends on stand age to describe density independent mortality (Jerez et al. 2015). Quadratic diameter growth is an output from basal area and stand density.

Model parameters were estimated based on a data set from trials and permanent/ temporal plots in plantations ranging from 2 to 32-yrs-old and located in the Western 
Plains of Venezuela (Tab. S1 and Tab. S2 in Supplementary material). Trials and plots were established on adequate climatic conditions for teak, i.e., precipitation 1500$2000 \mathrm{~mm}$, a dry season of three to four months, average temperature of $26-28{ }^{\circ} \mathrm{C}$; soil of alluvial origin (entisols, inceptisols, alfisols, and entisols), where the physiographic position determines soil physical and chemical properties and drainage. Plantations were different in soil quality, as reflected by the site index equations and management (initial spacing and thinning schedules). Over $\left(V_{\mathrm{ob}}\right)$ and under bark $\left(\mathrm{V}_{\mathrm{ub}}\right)$ total volumes were estimated for standing trees according to Moret et al. (1998 - eqn. 2, eqn. 3)

$$
\begin{aligned}
& V_{o b}=0.260 \cdot\left(d^{2} h\right)^{0.964} \\
& V_{u b}=0.343 \cdot\left(d^{2} h\right)^{0.934}
\end{aligned}
$$

where $d$ is diameter at breast height $(\mathrm{cm})$ and $h$ is the total height $(\mathrm{m})$.

\section{Carbon balance}

For each year of the planning horizon, the net carbon balance (i.e., storage minus emissions) for each stand was calculated based on the amount of carbon stored in aboveground and belowground biomass. Carbon emissions during the rotation period included the decomposition of carbon stored in woody and foliage debris remaining in the stand after thinning or harvest, as well as the emissions from decomposition of merchantable products after harvest and processing. The model does not explicitly describe the carbon stored or released from the soil, emissions from harvest operations, products transport (i.e., carbon emitted by trucks and machinery), product recycling, or effects of substituting fossil fuels by wood. Similar approaches were used in other forest planning works (Díaz-Balteiro \& Rodriguez 2006, Baskent et al. 2008).

\section{Carbon storage from the biomass}

To estimate the stem biomass, the outputs of the growth and yield model were taken as inputs for the sub-model 2. Woody biomass dry weight was assessed from stem timber volume based on the basic density of teak wood ( $0.54 \mathrm{Mg} \mathrm{m}^{-3}$ - Pérez \& Kakkinen 2005). Further, a biomass expansion factor (1.33) was used to estimate the total aboveground biomass (leaves, branches, and stem) as a function of the stem biomass (Kraenzel et al. 2003). Dry belowground biomass (roots and fine roots) was derived from the aboveground biomass using a shoot-root ratio of 0.16 (IPCC 2005); finally, the carbon content was estimated as a fraction (0.495) of the total dry biomass (see Tab. S3 in Supplementary material).

\section{Carbon emissions}

The estimation of carbon emissions from the decomposition of harvest residues (such as roots, branches, stumps, and dead wood) was included in sub-model 2 . The rates of carbon emissions generated by the forest products after harvesting or thinning were projected according to product classes: (i) long (i.e. large solid wood products), (ii) medium, and (iii) short duration. According to Hoen \& Solberg (1994), carbon emission processes were simulated by considering future carbon emissions as a function of decomposition rates and the organic lifetime of harvested wood products ("anthropogenic" time). According to this model, the removal in each period was assigned to a certain number of final "use categories", each with different emission rates. In the time period $i+j$, the carbon emission $E_{i k, i+j}$ from biomass of category $k$ removed at time $i$ was calculated as follows (eqn. 4):

$$
E_{i k, i+j}=B E_{i} \cdot e_{k} \cdot Q_{k, i+j}
$$

where $B E_{i}$ is the removed biomass at time $i$, $e_{k}$ is the fraction of removed total biomass assigned to the use category $k$, and $Q_{k, i+j}$ is the emission rate of product $k$ in the time interval $i+j$, which was calculated as (eqn. 5):

$$
Q_{k, i+j}= \begin{cases}0 & \text { if } j \leq A_{T k} \\ \left(1-q_{k}\right)^{j-A_{T k}} & \text { if } j>A_{T k}\end{cases}
$$

where $A_{T k}$ is the "anthropogenic" time for the use category $k, q_{k}$ is the annual fraction of decomposition for category $k$, which can be obtained using eqn. 6 :

$$
q_{k}=1-0.1^{1 / D_{T k}}
$$

Eqn. 6 implies that the biomass in each category decomposes as a constant proportion of the remaining biomass. For each use category, emission and decomposition will stop when a very tiny fraction $(<0.01$ $\mathrm{MgC} \mathrm{ha-1)}$ is emitted. Thus, a small fraction of biomass will not further decompose, e.g., soil organic carbon (Hoen \& Solberg 1994). In addition, carbon emission patterns are not appreciably affected by carbon mineralization processes.

Seven use categories were considered in the model: (1) roots; (2) deadwood; (3) branches and stumps; (4) bark and debris; (5) short duration wood products (small poles for fencing); (6) midterm duration products (struts and large poles); and (7) long term duration products (sawn timber). Decomposition time $\left(D_{T}\right)$ and anthropogenic time $\left(A_{T}\right)$ were taken from Hoen \& Solberg (1994) and are summarized in Tab. S4 (Supplementary material). The proportions of wood products per category for teak trees were taken from Osorio (1997), and are listed in Tab. S5 (Supplementary material).

\section{Optimization of the stand-level model}

We developed a restricted optimization model using integer variables to represent ages of thinning, and continuous variables for thinning intensities (percentages of the stand basal area).

The objective function was (eqn. 7):

$$
\operatorname{Max} N P V_{\text {total }}=N P V_{\text {wood }}+N P V_{\text {carbon }}
$$

where $N P V_{\text {wood }}$ and $N P V_{\text {carbon }}$ are the net present value (US\$) of merchantable wood and the net present value (US\$) of carbon stored, respectively. The decision variables were: (i) the number of years from planting (year 0 ) to first thinning, or the number of years between successive thinnings $\left(A_{i}\right)$, where $j$ represents the $j$-th thinning; (ii) the thinning intensity, expressed as the percentage of the stand basal area removed by the $j$-th thinning $\left(I_{j}\right)$.

The model constraints were (eqn. 8 to eqn. 14):

$$
\begin{aligned}
& G o_{i+1}=G f_{i}+\Delta G_{i+1, i} \\
& \text { Gthin }_{i}=I_{i} \cdot G_{i} \\
& G f_{i}=G o_{i}-\text { Gthin }_{i} \\
& A_{1} \geq 5 \\
& A_{j} \geq 3 \forall j \\
& I_{j} \geq 25 \forall j \\
& A_{j}=\text { integer } \forall j
\end{aligned}
$$

where $\mathrm{Go}_{\mathrm{i}}$ is the basal area at the beginning of the $i$-th year $\left(\mathrm{m}^{2} \mathrm{ha}^{-1}\right), G f_{\mathrm{i}}$ is the basal area at the end of the $i$-th year $\left(\mathrm{m}^{2} \mathrm{ha}^{-1}\right), \mathrm{Gthin}_{\mathrm{i}}$ is the basal area thinned in the $i$-th year $\left(\mathrm{m}^{2}\right.$ $\left.h^{-1}\right)$ and $\Delta G_{i+1, i}$ is the current annual increment of basal area $\left(\mathrm{m}^{2} \mathrm{ha} \mathrm{a}^{-1}\right)$.

Constraint in eqn. 11 indicates that the minimum age for the first thinning is five year-old. This is a common practice used to obtain a small amount of commercial products. Sometimes thinning is done at age 3 to favor early diameter growth; however, there are no studies indicating that this is a financially optimal decision. Eqn. 12 implies that at least three years must elapse between successive thinnings. From a practical point of view, there are logistical problems to organize and execute thinnings too often. Constraint in eqn. 13 avoids the removal of very few trees in a given thinning, because the growth response of remaining trees would be negligible and the operational costs high.

\section{Optimization of the forest-level model}

A binary variable constrained optimization was modeled to achieve the optimum harvest plan. The objective function was (eqn. 15):

$$
\operatorname{Max} F=N P V_{\text {wood }}+N P V_{\text {carbon }}+S I
$$

where $N P V_{\text {wood }}$ is the net present value of cash flows incoming during the planning period due to timber harvested, $N P V_{\text {carbon }}$ is the NPV of cash flows due to positive net carbon storage, and SI is a "spatial index" 
that aggregates forest operations, in such a way the stands to be cut at a given time are as close as possible to each other and to the main road.

The net present value of merchantable timber was calculated as follows (eqn. 16):

$$
N V P_{\text {wood }}=\sum_{i=1}^{n r} \sum_{j=1}^{m_{i}} \sum_{k=1}^{a} X_{i j} \cdot \frac{I_{i j k}-C_{i j k}}{(1+r)^{k}}
$$

where $\mathrm{nr}$ is the number of stands considered, $m_{i}$ is the number of alternative management regimes for the stand $i, a$ is the number of years of the planning period, $r$ is the interest rate. The term $l_{\mathrm{ijk}}$ represent the incomes from timber harvested in the stand $i$ for the year $k$ when the management regime $j$ is applied. These incomes result from multiplying the harvested volume by the price per cubic meter of timber. Prices are for roundwood and vary depending on log average diameter. The term $C_{\mathrm{ijk}}$ is the total costs for stand $i$ in year $k$ for a given management $j$, and include the harvest costs which vary according to the extracted volume, costs of stand establishment and tending, and transporting timber to the sawmill.

The net present value of carbon was calculated as follows (eqn. 17):

$$
N P V_{\text {carbon }}=P_{c} \sum_{i=1}^{n r} \sum_{j=1}^{m_{i}} \sum_{k=1}^{T d} X_{i j} \cdot \frac{F_{i j k}-E_{i j k}}{(1+r)^{k}}
$$

where $P_{c}$ is the carbon price (US\$ $\mathrm{Mg}^{-1}$ of C), $\mathrm{nr}$ is the number of stands considered, $m_{i}$ is the number of alternative management regimes for stand $i, T d$ is the time (years) at which $90 \%$ of carbon of the product with the largest organic life span has been emitted to the atmosphere. $F_{\mathrm{ijk}}$ is the carbon fixed ( $M g$ of $C$ ) in the stand $i$ in year $k$ under the management regime $j$; and $E_{i j k}$ is the carbon emitted ( $\mathrm{Mg}$ of $\mathrm{C}$ ) by the stand $i$ in year $k$ if the management regime $j$ is applied; and $r$ is the interest rate.

The spatial index $(\mathrm{SI})$ proposed by Chen \& Gadow (2008) was calculated for each year $k$ of the planning period (eqn. 18):

$$
S I_{k}=\sum_{i=1}^{n r} \sum_{w=1}^{n r} \frac{R_{i w k}}{d_{i w}}
$$

with $\mathrm{i} \neq \mathrm{w}$, where $S I_{k}$ is the spatial index for the year $k, n r$ is the number of stands, $R_{\text {iwk }}$ is a binary variable taking the value of 1 if the stands $i$ and $w$ are cut in the year $k$ and 0 in any other case, $d_{i w}$ is the distance between the stands $i$ and $w$. Thereafter, the Sl's for all years were added up to obtain a SI for the harvest plan (eqn. 19):

$$
S I=P_{i e} \sum_{k=1}^{a} S I_{k}
$$

where $P_{\mathrm{ie}}$ is the weight or penalty imposed to the $S I$ for balancing its value with $N P V_{\text {wood }}$ and $N P V_{\text {carbon }}$ in the objective function, and $a$ is the number of years of the planning period.

The decision variables $\left(X_{\mathrm{ij}}\right)$ were binary variables taking the value of $1\left(X_{i j}=1\right)$ when the management regime $j$ is assigned to the stand $i$, and $X_{i j}=0$ otherwise.

Management regime was defined based on initial spacing, thinning regime, and the final harvest age. Thinning ages and intensities were determined by sub-model 1 depending on the planting year of stands and the age of last thinning, which must be done at least three years before the final harvest. The constraints were (eqn. 20 to 22):

$$
\begin{gathered}
\sum_{i=1}^{n r} \sum_{j=1}^{m_{1}} V E_{i j k} \geq C P_{k} \\
\sum_{j=1}^{m_{i}} X_{i j}=1 \\
x_{i j}=(0,1)
\end{gathered}
$$

with $k=1,2, \ldots, a ; i=1,2, \ldots, n r ;$ and $j=1,2$, ..., $m_{i}$, where $n r$ is the number of stands, $m_{i}$ is the number of alternative regimes for stand $i, V E_{i j k}$ is the volume harvested from the stand $i$ in year $k$ under the $j$-th management regime, $C P_{k}$ is the timber production quote for year $k$ and $a$ is the number of years of the planning period.

Constraint in eqn. 20 refers to the annual quota of timber. Constraint in eqn. 21 implies that a given stand can undergo only a unique management regime. Constraint in eqn. 22 indicates that decision variables must be binary.

\section{Optimization techniques and implementation}

The existence of nonlinear relationships among integer and continuous decision variables, and the model structure make extremely difficult to solve the above equations with classic mathematical techniques; therefore, heuristic techniques were used.

For solving sub-model 1, we used Genetic Algorithms (GA), a robust and efficient technique successfully applied to find optimal or close-to-optimal solutions when exact methods are difficult to implement (Dréo et al. 2006). To obtain the best thinning regimes for each stand, we developed a GA using a roulette wheel selection, two point crossover, and mutation of the solutions.

An optimization algorithm based on Simulated Annealing (SA) was incorporated in sub-model 2 in order to search for the best management plans at the forest level. The SA technique has been previously applied to forest harvest planning (Pukkala \& Kurttila 2005, Liu et al. 2006, Quintero et al. 2010, 2011), and has proven to achieve solutions very close to a mathematical optimum. The SA algorithm uses random initial solutions and a geometric cooling schedule. We implemented the model in Visual Basic 2010.

\section{Study case}

\section{Description and assumptions}

We used the data set obtained from teak plantations in Venezuela (described above) to simulate a teak plantation covering
10,000 ha and comprising 200 stands (50 ha each). Simulated stands differed in initial spacing, with 100 stands having an initial density $\left(D_{i}\right)$ of 1600 trees ha ${ }^{-1}(2.5 \times 2.5$ $\mathrm{m})$ and the remaining 100 stands having $D_{i}$ $=1111$ trees ha ${ }^{-1}(3.0 \times 3.0 \mathrm{~m})$. Moreover, the simulated stands differed in site quality: for each type of initial spacing, 50 stands were assigned to site quality I (SQ I), with a site index of $27 \mathrm{~m}$ (base age 16 years) and maximum basal area $\left(G_{\mathrm{p}}=37.5 \mathrm{~m}^{2}\right.$ ha-1), while 50 stands were assigned to site quality II (SQ II - site index = $\left.24 \mathrm{~m} ; G_{\mathrm{p}}=32.0 \mathrm{~m}^{2} \mathrm{ha}^{-1}\right)$.

The planning project spanned 40 years, from initial planting of the first stand until the final harvest of the last stand. Stand planting took place in the first ten years of the project (o to 10). The timber goal was to obtain merchantable wood from logs $\geq$ $20 \mathrm{~cm}$ in diameter. At the end of the planning period (40 years), all stands should have been harvested. We assumed that stands were not replanted after harvest, thus allowing for secondary vegetation to recover and some teak trees to re-sprout; however, the additional carbon sequestration of these abandoned stands was not considered in the project.

A different associated transport cost (in US\$ $\mathrm{m}^{-3}$ ) was assigned to each stand, depending on its distance from the sawmill. Roundwood prices were assigned according to diameter classes (between 53 and 400 US $\$ \mathrm{~m}^{-3}$ - see Tab. S6 in Supplementary material), and base carbon price was 10 US\$ $\mathrm{Mg}^{-1}$ of $\mathrm{C}$, as commonly used in financial analyses (Álvarez 2009).

\section{Optimization objectives}

Three alternative management scenarios were set with the objective of maximizing: (A) total NPV for merchantable timber production only; (B) total NPV for both timber and carbon sequestration; (C) total NPV for carbon sequestration only.

\section{Sensitivity analysis}

We carried out a three-stage sensitivity analysis for scenario B only (Timber production $+C$ sequestration). The stage 1 consisted of a sensitivity analysis for individual stands (sub-model 1). The magnitude of changes in the optimal solution was analyzed considering changes in harvest costs, interest rates, growth rates, timber prices, and carbon prices. Sensitivity was tested for: (i) growth rate $(k)$ at intervals of $\pm 1 \%$, within a biologically reasonable range (e.g., possible increase in growth rates due to fertilization); (ii) thinning and harvest costs between \pm 10 and $\pm 50 \%$ from the base value (14.24 US\$ $\mathrm{m}^{-3}$ ) at $10 \%$ intervals; (iii) interest rate from 2 to $14 \%$ (base value $10 \%$, which is the common range of discount rates in forestry projects; (iv) price carbon increments of 20,30,40,50, 100, 150 , and 200 US\$ $\mathrm{Mg}^{-1}$; and (v) differences in timber prices per cubic meter due to log dimensions. The price of teak timber depends largely on log size and age, as large logs with a high proportion of heartwood 
are best for teak products (e.g., furniture, plywood). For young teak plantations, wood quality and log dimensions are highly correlated. Four scenarios were considered: (1) all diameter classes have the same price in US\$ $\mathrm{m}^{-3}$ (i.e., no premium for large diameter logs); (2) logs with diameter (d) $\geq$ $25 \mathrm{~cm}$ are twice the value of logs $10 \leq d \leq 25$ $\mathrm{cm}$; (3) logs with $d \geq 25 \mathrm{~cm}$ are three times the value of $10 \leq d \leq 25 \mathrm{~cm}$ logs; and (4) logs with size $d \leq 10 \mathrm{~cm}$ have no value as timber product.

At stage 2 we carried out a sensitivity analysis for changes at forest level considering the sensitivities obtained in stage 1 (stand level), as changes in the optimal solution at stand level propagate to the forest level changing the optimum harvest plan. If no changes occurred at the stand level for a given variable, then the sensitivity analysis was carried out at the forest level for that variable. Finally, in stage 3 we carried out an additional sensitivity analysis at forest level, but considering only forestlevel input variables such as transport costs from the stands to external roads and production quotas. Transport costs were changed from the base costs up to $\pm 50 \%$, at $10 \%$ intervals for each of the four categories. We tested the model sensitivity to modifications of the annual production quota by raising or lowering the quota in certain periods (Tab. S7 in Supplementary material).

\section{Model validation}

Bettinger et al. (2009) proposed a classification of validation approaches for forest planning models according to problem particularities, model complexity, and availability of exact solutions. We carried out a "level 2" validation (known as "self-validation") by assessing the robustness of the solution through a statistical approach. Using this method, a sample set of solutions is required, each having a different objective function value easily obtainable from heuristics using stochastic processes such as simulated annealing and genetic algorithms (Bettinger et al. 2009). This type of validation is considered appropriate when a well-understood heuristic technique is applied to a new management problem, as it is our case.

The above validation approach was carried out at both stand and forest levels for the scenario of simultaneously optimizing timber production and carbon sequestration (scenario B). Fifty runs at each planning level were done and the optimum NPV and its basic statistics were recorded.

\section{Results}

\section{Stand level}

The developed model simulated the best thinning regimes for each stand according to initial spacing and site quality under the optimization scenarios. For those scenarios that included timber production, either alone (scenario A) or combined with car-

Tab. 1 - Net present value (NPV) of the best thinning regimes for teak stands (initial density: 1600 trees ha ${ }^{-1}$; Site quality: I; Rotation age: 30 ) for scenarios: A (wood production only); B (wood production and carbon sequestration); C (carbon sequestration only). (NT): number of thinnings for each regime. For each thinning, the age (years) and the percentage of removed basal area (in parentheses) are reported.

\begin{tabular}{|c|c|c|c|c|c|c|}
\hline \multirow{2}{*}{ Scenario } & \multirow{2}{*}{ NT } & \multicolumn{4}{|c|}{ Thinnings } & \multirow{2}{*}{$\begin{array}{c}\text { NPV } \\
(\text { US\$ ha-1) }\end{array}$} \\
\hline & & First & Second & Third & Fourth & \\
\hline $\mathrm{A} / \mathrm{B}$ & 0 & - & - & - & - & A: 7100; B: 1390 \\
\hline$A / B$ & 1 & $9(79.9)$ & - & - & - & A: $6290 ; B: 6780$ \\
\hline$A / B$ & 2 & $5(55.8)$ & $14(53.7)$ & - & - & A: $8980 ; B: 9470$ \\
\hline$A / B$ & 3 & 5 (46.5) & $10(47.7)$ & $19(29.0)$ & - & A: $9090 ;$ B: 9580 \\
\hline$A / B$ & 4 & $8(44.6)$ & $16(25.6)$ & $20(47.7)$ & $25(26.7)$ & A: $7900 ; B: 8470$ \\
\hline $\mathrm{C}$ & 0 & - & - & - & - & 680 \\
\hline $\mathrm{C}$ & 1 & 27 (27.9) & - & - & - & 672 \\
\hline $\mathrm{C}$ & 2 & $23(25.2)$ & $27(25.7)$ & - & - & 670 \\
\hline $\mathrm{C}$ & 3 & $20(26.2)$ & $24(27.4)$ & $27(48.1)$ & - & 666 \\
\hline $\mathrm{C}$ & 4 & $17(26.0)$ & $21(25.4)$ & $24(36.3)$ & $27(39.0)$ & 651 \\
\hline
\end{tabular}

bon sequestration (scenarios $B$ ), the best thinning regimes were the same, but they differed only in the magnitude of NPV total, which was larger when both objectives were considered. On the other hand, when $\mathrm{NPV}_{\text {carbon }}$ was the only optimization/maximization goal (scenario $\mathrm{C}$ ), thinnings were prescribed at later ages and lower intensities. For example, for scenario $A\left(D_{i}=1600\right.$ trees $\mathrm{ha}^{-1}, \mathrm{SQ}=\mathrm{I}$, harvest age $=30$ ), the best thinning regime for scenarios $A$ and $B$ consisted of three thinnings at ages 5,10 , and 19 , removing $46.5 \%, 47.7 \%$, and $29 \%$ of the total basal area, respectively (Tab. 1). Contrastingly, when the goal was carbon sequestration (scenario $\mathrm{C}$ ), the best option was no thinning.

\section{Forest level}

We ran the model to obtain the optimal harvest sequence for 200 stands during the planning period under the proposed scenarios. For each year, the model indicated which stands should be thinned or harvested to maximize the expected benefits. Again, the simulated $\mathrm{NPV}_{\text {total }}$ value obtained for the scenario B (both optimization crite-

Tab. 2 - Rotation age for stands under optimal planning schedules for each management scenario: (A) Wood production; (B) Wood production + carbon sequestration; (C): Carbon sequestration.

\begin{tabular}{lccccccc}
\hline \multirow{2}{*}{ Scenario } & \multicolumn{2}{c}{ Clearcut age (years) } & & \multicolumn{2}{c}{$\begin{array}{c}\text { Clearcut stands } \\
\text { (age }<25\end{array}$} & \multicolumn{2}{c}{$\begin{array}{c}\text { Clearcut stands } \\
\text { (age } \geq 25\end{array}$} \\
\cline { 2 - 8 } & Average & Min & Max & N & $\%$ & N & $\%$ \\
\hline A and B & 27.2 & 20 & 38 & 61 & 30.5 & 139 & 69.5 \\
C & 30.5 & 20 & 39 & 25 & 12.5 & 175 & 87.5 \\
\hline
\end{tabular}

Tab. 3 - Number of stands with a given number of prescribed thinnings under the optimization scenarios: (A) wood production only; (B) wood production + carbon sequestration; (C): carbon sequestration only.

\begin{tabular}{lcccccc}
\hline \multirow{2}{*}{ Scenario } & \multicolumn{7}{c}{ Number of thinnings } & \multirow{2}{*}{ Total } \\
\cline { 2 - 6 } & $\mathbf{0}$ & $\mathbf{1}$ & $\mathbf{2}$ & $\mathbf{3}$ & $\mathbf{4}$ & \\
\hline A and B & 29 & 39 & 55 & 55 & 22 & 200 \\
C & 62 & 39 & 38 & 31 & 30 & 200 \\
\hline
\end{tabular}


Tab. 4 - Net present value for wood (NPV wood $)$ and carbon sequestration ( $\left.\mathrm{NPV}_{\text {carbon }}\right)$ according to optimization objectives.

\begin{tabular}{lccc}
\hline \multirow{N}{*}{ NPV } & \multicolumn{2}{c}{ Optimization objectives } & Difference \\
\cline { 2 - 3 } & $\begin{array}{c}\text { Wood } \\
\text { production }\end{array}$ & $\begin{array}{c}\text { Carbon } \\
\text { sequestration }\end{array}$ & (US\$ million) \\
\hline NPV $_{\text {wood }}$ (US\$ million) & 31.03 & 8.08 & -22.95 \\
$\mathrm{NPV}_{\text {carbon }}$ (US\$ million) & 8.47 & 11.94 & +3.47 \\
Total NPV & 39.50 & 20.04 & - \\
\hline
\end{tabular}

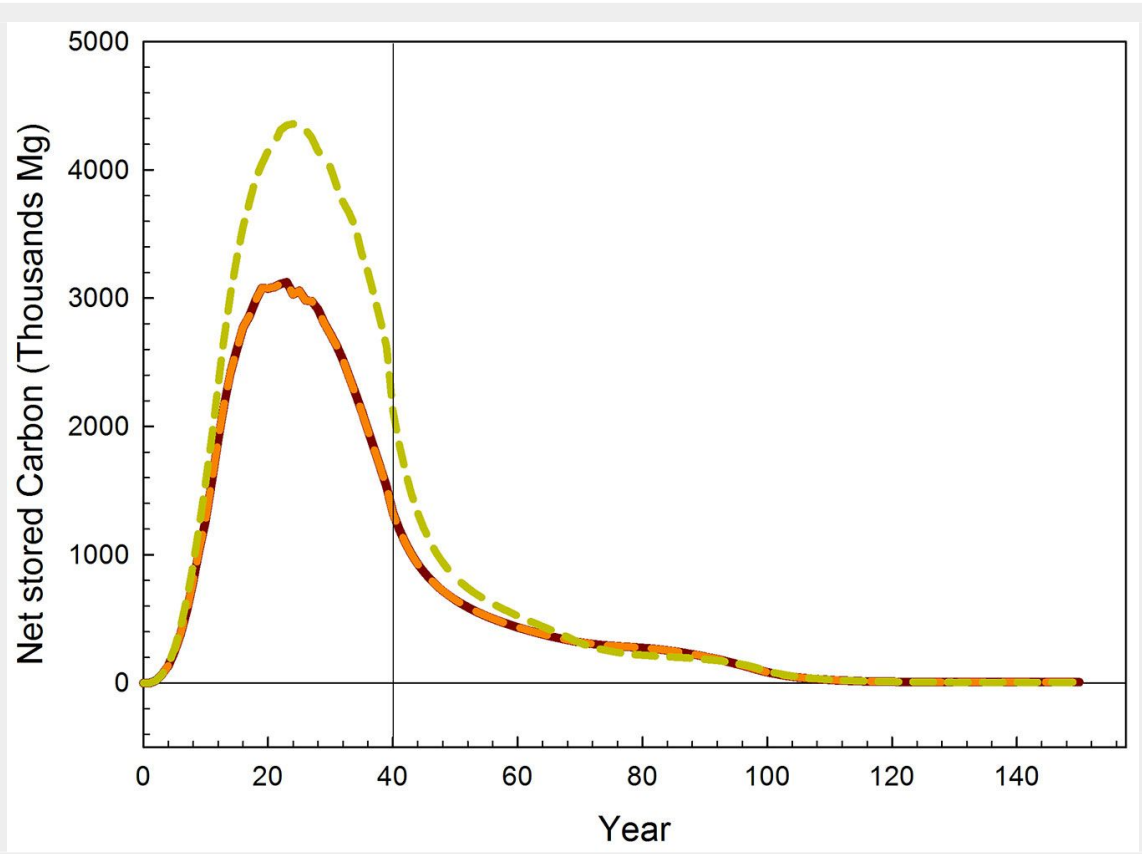

Fig. 2 - Dynamics of net carbon storage (from total accumulated biomass). Average life cycle of carbon stored as wood in standing trees, forest products, and harvest residues for a 10,000 ha teak plantation under the base optimization scenarios (maximum NPV criteria). Carbon price $10 \mathrm{US} \$ \mathrm{Mg}^{-1}$ of $\mathrm{C}$ and timber prices between 53 and 400 US\$ $\mathrm{m}^{-3}$ according to log size categories (Tab. S6 in Supplementary material). (Scenario 1): maximizing NPV for carbon sequestration (green dashed line); (scenario 2): maximizing NPV of wood production only (orange dashed line); (scenario 3): Maximizing NPV of wood and carbon simultaneously (brown line).

of the teak plantation project, the potential benefits of wood production predicted by the model decreased by $73.9 \%$. Contrastingly, maximizing NPV ${ }_{\text {wood }}$ as the sole objec tive decreased the predicted benefits from carbon sequestration by $29 \%$. Thus, given the base scenarios and the model assumptions, it seems not attractive to manage teak plantations with the only aim of carbon sequestration.

Tab. 5 - Sensitivity analysis for selected variables. Data indicate the ranges in which the optimal solution (harvest patterns) is modified with respect to the base solution.

\begin{tabular}{lcc}
\hline Variable / Parameter & $\begin{array}{c}\text { Model sensitive to } \\
\text { changes (range) }\end{array}$ & $\begin{array}{c}\text { Model not sensitive } \\
\text { to changes (range) }\end{array}$ \\
\hline Basal area growth rate & {$[0.10,0.25]$} & None \\
Harvest cost & None & {$[7.12,21.36]$ US\$ m } \\
Interest rate & $>10 \%$ & $<10 \%$ \\
Wood prices & All scenarios & No scenarios \\
Carbon price & $\geq 40$ US\$ $\mathrm{Mg}^{-1}$ of C & {$[0,40]$ US\$ $\mathrm{Mg}^{-1} \mathrm{C}$} \\
Transport cost & None & All scenarios \\
Production quotas & Scenarios $1-4$ & Scenarios $5-8$ \\
\hline
\end{tabular}

model tended to minimize the number and intensity of thinnings, and to delay the thinnings and final harvest ages to defer the beginning of $C$ emissions. In other words, the model favored net $\mathrm{C}$ storage to increase the value of the objective function, by avoiding large $\mathrm{C}$ emissions due to cutting operations, as emissions due to mortality of standing trees were small.

In our model, at the year 40 all stands not harvested during the project life were cut $\left(76,879 \mathrm{~m}^{3}\right.$ in the A-B scenarios, and $273,600 \mathrm{~m}^{3}$ in scenario $\mathrm{C}$ ), thus the largest part of the carbon previously sequestered was kept as merchantable products and as debris from harvest and wood processing. In scenario C (max NPV carbon), the amount of carbon stored remained larger until year 69 , because the final harvest was much larger than in scenario A, but as short to medium duration products. On the other hand, in scenario $A$ ( $\max N P V_{\text {wood }}$ ), the total amount of $C$ stored as harvested products was lower, but as long duration products. In both scenarios, the remaining fraction of carbon returned to the atmosphere, according to decomposition and anthropogenic times for products and debris; hence, the curve for scenario $C$ decreased gradually (Fig. 2). Likewise, during this period, emissions before year 40 continued according to the assumed decomposition rates. After that year, most $C$ stored in short and medium duration products has been released back to the atmosphere. Thus, the total carbon that remains stored in scenario $C$ is the largest, because it comprises long duration products. After year 116 almost all $C$ has been released, remaining a small fraction that never decomposes or is incorporated into the soil as organic $C$ (Hoen \& Solberg 1994). Consequently, the curves for scenarios A and B were similar (Fig. 2).

\section{Sensitivity analysis}

The model was very sensitive to changes in growth rates of basal area and in timber prices, as very small changes generated different optimum harvest plans. In addition, the model was sensitive to changes in interest rates by changing the optimal solutions in terms of thinning regimes and harvest ages (Tab. 5). Nevertheless, for interest rates between 6 and 10\% the optimum harvest plan did not change. Regarding carbon prices, the sensitivity analysis indicated that the optimal solution (harvest plan) changed when the prices reached 40 US\$ $\mathrm{Mg}^{-1} \mathrm{C}$. In such case, the optimum thinning ages occurred later and thinning intensities were lower.

Changes in allowable production quotas for the whole project modified the optimal harvest plan. When annual quotas were raised from five to $10,000 \mathrm{~m}^{3}$ between the years 7 and 20 (scenarios 1, 2, 3- Tab. S7 in Supplementary material), the optimum harvest plan changed because thinning regimes and final harvest for each stand changed to meet the new quotas. When 
the quota for years 21-40 rose from 60 to $65,000 \mathrm{~m}^{3}$, an optimal solution could not be found. For scenarios where production quotas were reduced (scenarios 5, 6, 7, 8 Tab. S7 in Supplementary material), the optimal solutions were the same as the base scenario; yet, volume yield per year surpassed the assigned annual quotas. Changes in harvest and transport costs did not change the optimal solution, thus the proposed model is not sensitive within the range of changes assumed for these variables.

\section{Model validation}

To validate the model, descriptive statistics for a sample of 50 solutions for the thinning regime sub-model (stand level) were produced considering one to four thinnings (Tab. 6). In all cases, the lowest $N P V_{\text {total }}$ differed by less than $28 \%$ from the maximum NPV (optimum). The percent difference between the lowest and highest NPV increased when more thinnings were carried out, indicating that the genetic algorithm was more precise when only one or two thinnings were prescribed (6.9 and $14.5 \%$, respectively). Furthermore, the variability of the solutions was larger in scenarios with more thinnings. This could happen because there are two types of decision variables: integer variables (representing thinning age) and continuous variables (representing thinning intensity); hence, an infinite number of combinations does exist. As more variables were included in the model, its complexity increased reducing the precision of the genetic algorithm.

At forest level, model validation showed that the difference between the highest and lowest NPV was $4.68 \%$ (Tab. 6). Thus, there is a strong confidence that the value obtained by just one model run falls within $5 \%$ of the best solution, therefore indicating a satisfactory performance of the simulated annealing algorithm. In addition, the small percent difference between the best value and the average value supports the robustness of the heuristic technique applied. The coefficient of variation of solutions produced for the forest level model (sub-model 2) was lower than that for the stand level sub-model (Tab. 6).

\section{Discussion}

The model proposed in this study simulates a full teak plantation project at the stand and forest levels and provides a optimized harvest plan by identifying which stands to thin or harvest each year in order to both maximize the benefits and meet the operating constraints. The simulation carried out in this study (200 stands, 10,000 ha) was solved by the model in a few seconds. The results obtained were satisfactory, considering the model complexity, assumptions and constraints. For example, for maximizing NPV wood, the model increased the number of thinnings and their intensities to favor larger diameter growth and logs with higher value as sawn timber.

Tab. 6 - Model validation. Net present value (NPV) statistics from 50 runs for the stand-level model and for the forest-level model. Study case: 10,000 ha teak plantation project. Statistics for NPV are: average, minimum (Min), maximum (Max), standard deviation (SD) in thousand US\$; and coefficient of variation in percentage (CV); (D1): percentage difference between the maximum value and the minimum value; (D2): percentage difference between the average and the maximum value; (NT): number of thinnings.

\begin{tabular}{|c|c|c|c|c|c|}
\hline \multirow{2}{*}{ Statistics } & \multicolumn{4}{|c|}{ Stand level } & \multirow{2}{*}{ Forest level } \\
\hline & $\mathrm{NT}=1$ & $\mathrm{NT}=2$ & NT $=3$ & NT $=4$ & \\
\hline Average & 6.55 & 8.83 & 8.70 & 7.12 & 38185.53 \\
\hline Min & 6.32 & 8.10 & 7.29 & 6.13 & 39500.00 \\
\hline Max & 6.78 & 9.47 & 9.58 & 8.47 & 37649.18 \\
\hline SD & 0.20 & 0.37 & 0.47 & 0.52 & 384.99 \\
\hline $\mathrm{CV}$ & 3.12 & 4.18 & 5.40 & 7.23 & 1.01 \\
\hline D1 & 6.87 & 14.48 & 23.95 & 27.67 & 4.68 \\
\hline D2 & 3.53 & 6.76 & 9.14 & 15.90 & 3.33 \\
\hline
\end{tabular}

Moreover, the simulated dynamics of the stand variables (diameter, basal area, stand density) were within the expected limits for acceptable quality teak stands in terms 2004, Pérez \& Kanninen 2005). Model sensitivity analysis indicated that stand growth rates and timber prices strongly influence optimal management plans obtainable, while interest rates, carbon price, and annual production goals had a lesser influence. Transport and plantation management costs appeared to have a low impact on the optimization of management plan. Chiari et al. (2008) found similar results when analyzed the sensitivity of a linear programming model for a large eucalyptus plantation project devoted to pulpwood production in Venezuela.

The proposed model can be usefully apof both growth and yield (Bermejo et al.

plied to optimize harvest plans in teak plantations by maximizing wood production and/or carbon sequestration as separate objectives or simultaneously. According to the model results, for a price of $10 \mathrm{US} \$ \mathrm{Mg}^{-1}$ of $C$ and the current timber prices (53-400 US $\$ \mathrm{~m}^{-3}$, depending on log diameter) there were no differences in cutting patterns (best thinning regimes and optimal harvest plan) between the scenario optimizing timber production (scenario $\mathrm{A}$ ) and that maximizing both wood production and $C$ sequestration (scenario $B$ ). This is because timber prices were much higher than the market carbon prices. The lack of differences between the above scenarios can be explained because the model is not sensitive to changes in $C$ prices between 0 and 40 US\$ $\mathrm{Mg}^{-1}$ (Tab. 5). C prices above 40 US\$ $\mathrm{Mg}^{-1}$ could make teak plantations for car-

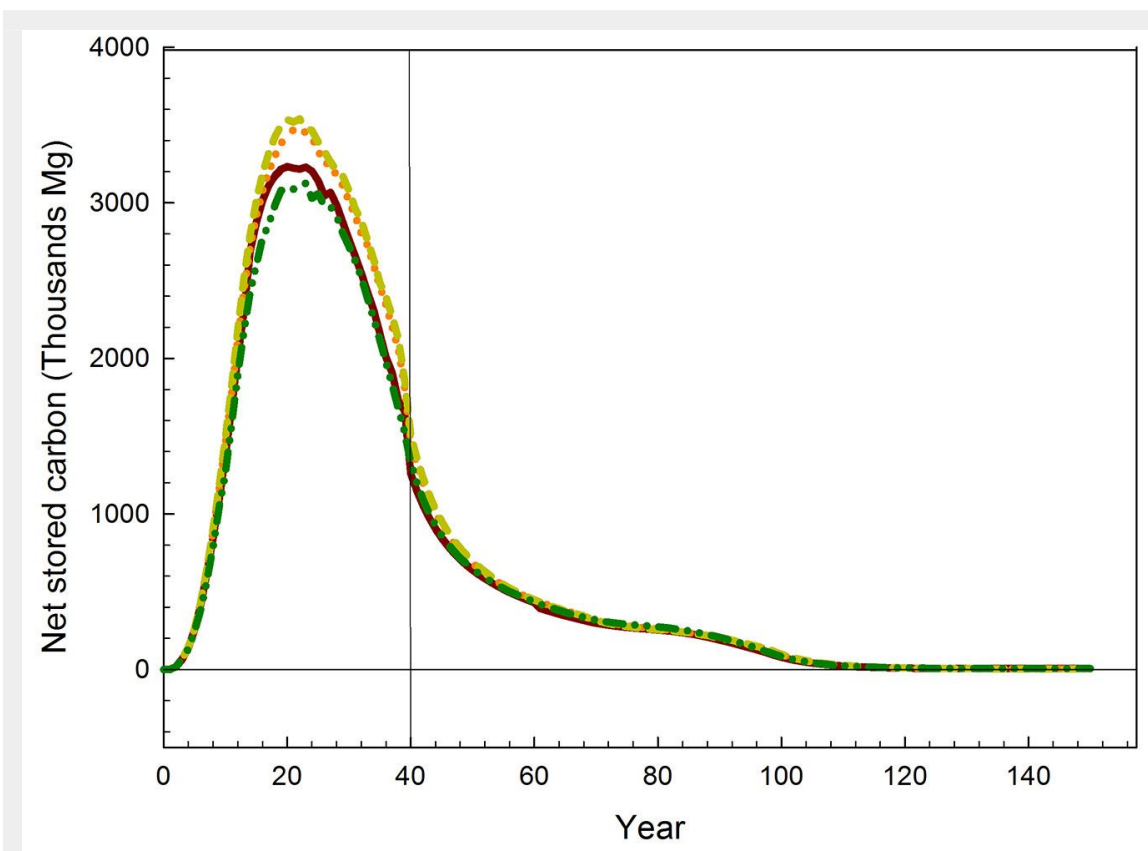

Fig. 3 - Dynamics of net carbon storage under scenarios of wood production only (dark green dashed line), wood + carbon sequestration (40 US\$ $\mathrm{Mg}^{-1}-$ brown solid line); wood + carbon sequestration (100 US\$ $\mathrm{Mg}^{-1}$ - orange dotted line), wood + carbon sequestration (150 US\$ $\mathrm{Mg}^{-1}$ - green dashed line). Timber prices are reported in Tab. S6 (Supplementary material). 
bon sequestration a more profitable option. Further, larger $C$ prices could allow stocking larger $C$ amounts before harvest, thus changing the harvest patterns and the net $C$ storage curves between the aforementioned scenarios (Fig. 3).

When maximization of $\mathrm{NPV}_{\text {carbon }}$ was set as the only management goal in the model, the generated harvest plans had lesser, later, and lower intensity thinnings, as well as longer rotations. Raymer et al. (2009) found similar results analyzing several management strategies for increasing the benefits from carbon sequestration in a forestland in Norway. Likewise, Bateman \& Lovett (2000) suggested to avoid thinnings for increasing carbon sequestration of plantations. Similarly, other authors found that carbon sequestration in plantations can be increased by delaying the final harvest ( $\mathrm{Li}-$ ski et al. 2001, Pussinen et al. 2002, Kaipanen et al. 2004). Therefore, the management regime may influence the capacity of a forest plantation to sequester carbon.

The simulations carried out revealed that maximizing for $\mathrm{NPV}_{\text {carbon }} \mathrm{C}$ stock in the plantation was larger until year 69 as compared to scenarios maximizing $\mathrm{NPV}_{\text {wood; }}$, however, for the latter scenarios a larger fraction of $C$ remained stored in long duration products until the year 116 .

Our results showed that implementing management plans to favor carbon sequestration reduce the economic benefits from timber production, and vice-versa, indicating that these objectives are in conflict, which is consistent with previous studies (Backéus et al. 2005, Raymer et al. 2009, Nepal et al. 2012). According to the model's results, with C prices of US\$10 $\mathrm{Mg}^{-1}$ managing teak plantations for carbon sequestration only is not attractive, because of the high market value of teak timber. For other tropical species with lower timber value used in plantations, such as pine or eucalyptus, optimizing for carbon sequestration could be more attractive, especially if environmental concerns are important. In such cases, considerations on the land value could be more critical to determine the feasibility of implementing carbon sequestration projects.

Our results suggest that teak has a good potential for carbon storage due to its fast growth and wood durability. Additional benefits could be obtained from $C$ sequestration only by optimizing the NPV wood $_{\text {, as long }}$ as $\mathrm{C}$ prices are below $40 \mathrm{US} \mathrm{Mg}^{-1}$. Managing teak projects as infinite rotation plantations would transform them in permanent carbon sinks, also increasing their capacity for soil carbon storage.

Most teak plantations, especially in Latin America, are small to medium size privateowned projects (i.e., 3,000-10,000 ha) made by several stands of different age, site quality, and extension. In addition, they are planned for limited time horizons (e.g., 30-40 years) and for only one rotation. Although the present study is based on simulations, such characteristics are si- milar to those implemented in the proposed model. However, the information required to model teak plantation management is mainly limited by two reasons: (i) companies are not willing to make public information on operational activities; and (ii) more than $80 \%$ of teak plantations in Latin America are less than 20 years old (De Camino \& Morales 2013), thus no company has completed the first rotation.

Although our model is calibrated on teak trees growing in the Venezuelan Western Plains (alluvial soils), growth and yield performances of teak stands are comparable with those observed in other countries, like Brazil, Mexico, Colombia, Ecuador, and other states of Central America, in terms of growth rates, mean annual increments (8$20 \mathrm{~m}^{3} \mathrm{ha}^{-1} \mathrm{yr}^{-1}$ ), yield, and financial results for a given site index. Moreover, volume and yield tables from Venezuela have been successfully extrapolated to other countries. However, we caution to extrapolate our results to Asian or African Countries, or to clonal plantations under intensive management. Furthermore, as the growth and yield model used is based on the basal area, its calibration to more site specific conditions and management regimes can be done with no risk of obtaining unrealistic results. Finally, the modular structure of the proposed model allows for changes in the growth and yield model without affecting the other model components.

So far, the high prices of high quality teak timber has reduced the need of harvest optimization techniques for increasing efficiency in timber production and planting operations. As many teak plantations are reaching commercial ages in Latin America, timber supply could exceed the demand, thus lowering timber prices. Further, certification of sustainability is increasingly required on the market for timber products from plantation projects, which implies many environmental requirements. In addition, many projects receive subsidies in their initial phases and are subject to enter the incipient carbon market. Thus, optimizing carbon sequestration and timber production in teak plantations is going to be crucial in the upcoming years.

\section{Conclusions}

In this study, a model was developed for optimizing both thinning regimes in individual teak stands and the harvest plan for the whole plantation, aimed at simultaneously maximizing timber production and carbon sequestration. The adopted modeling approach allowed the integration of both stand and forest planning levels. At the stand level, we approached the stockingregime optimization problem using a heuristic model based on Genetic Algorithms. Production curves were generated according to stand characteristics by a forest stand growth and yield simulator. At forest level, we used a simulated annealing heuristic technique to determine optimal harvest ages and assign an appropriate thin- ning regime to each stand matching the annual production quotas.

The proposed harvest planning model may help managing small to large scale teak plantations, by providing information on plantation growth and yield, and considering the impact of stocking and harvest regimes. The possibility of quickly running and examining several potential harvest plans under various scenarios makes the model useful as a starting point for designing management plans, fieldwork task assignments, road construction, and equipment displacement.

\section{Acknowledgements}

This work was supported by the Consejo de Desarrollo Científico, Humanístico, Tecnológico y de las Artes (CDCHTA), Universidad de Los Andes (ULA), Mérida, Venezuela [Grant FO-705-11-01-B] and by the Genética and Silvicultura Research Team, Instituto de Investigaciones para el Desarrollo Forestal, ULA. We are grateful to Dr. Thomas J. Dean, Dr. Lawrence W. Vincent, Dr. Magdiel Ablan and Dr. Miguel Acevedo. We also thank two anonymous reviewers for their useful comments and advices.

\section{References}

Álvarez S (2009). Optimización de la plantación forestal considerando la captura de carbono en bosque de pino-encino en la sierra Suárez, Oaxaca, México [Optimizing the plantation forest considering carbon capture in the pine-oak forest in Suárez range, Oaxaca, México]. Universidad Politécnica de Madrid, Escuela Técnica Superior de Ingeniero de Montes, Madrid, Spain, pp. 174. [in Spanish]

Backéus S, Wikströn P, Lämås T (2005). A model for regional analysis of carbon sequestration and timber production. Forest Ecology and Management 216: 28-40. - doi: 10.1016/j.foreco. 2005.05.059

Baskent EK, Keles S, Yolasigmaz HA (2008). Comparing multipurpose forest management with timber management, incorporating timber, carbon and oxygen values: a case study. Scandinavian Journal of Forest Research 23: 105-120. - doi: 10.1080/02827580701803536 Bateman IJ, Lovett AA (2000). Estimating and valuing the carbon sequestered in softwood and hardwood trees, timber products and forest soils in Wales. Journal of Environmental Management 60: 301-323. - doi: 10.1006/jema.20 00.0388

Bermejo I, Cañellas I, San Miguel A (2004). Growth and yield models for teak plantations in Costa Rica. Forest Ecology and Management 189: 97-110. - doi: 10.1016/j.foreco.2003.07.031 Bettinger P, Chung W (2004). The key literature of, and trends in, forest-level management planning in North America, 1950-2001. International Forest Review 6: 40-50. - doi: 10.1505/ifor. 6.1.40.32061

Bettinger P, Sessions J, Boston K (2009). A review of the status and use of validation procedures for heuristics used in forest planning. International Journal of Mathematical and Computational Forestry and Natural-Resource Sciences 1: 126-137. [online] URL: http://search. 
proquest.com/openview/od684ca546b2aece74 9d3ebf6ac13479/1

Bravo F, Bravo-Oviedo A, Diaz-Balteiro LD (2008). Carbon sequestration in Spanish Mediterranean forests under two management alternatives: a modeling approach. European Journal of Forest Research 127: 225-234. - doi: 10.1007/s10342-007-0198-y

Cao T, Valsta L, Mäkelä A (2010). A comparison of carbon assessment methods for optimizing timber production and carbon sequestration in Scots pine stands. Forest Ecology and Management 260: 1726-1734. - doi: 10.1016/j.foreco.20 10.07.053

Chen BW, Gadow KV (2008). Combining spatial and other objectives in forest design. Forestry Studies 48: 30-40. - doi: 10.2478/v10132-011-005 3-2

Chiari R, Carrero O, Jerez M, Quintero MA, Stock $J$ (2008). Modelo preliminar para la planficación del aprovechamiento en plantaciones forestales industriales en Venezuela [Preliminary harvest planning model for industrial forest plantations in Venezuela]. Interciencia 33: 802-809. [in Spanish]

Cubero J, Rojas S (1999). Fijación de carbono en plantaciones de melina (Gmelina arborea Roxb.), teca (Tectona grandis L. f.) y pochote (Bombacopsis quinata Jacq.) en los cantones de Hojancha y Nicoya, Guanacaste, Costa Rica [Carbon fixation in melina (Gmelina arborea Roxb.), teak (Tectona grandis L. f.) and pochote (Bombacopsis quinata Jacq.) plantations in the cantons of Hojancha and Nicoya, Guanacaste, Costa Rica]. Escuela de Ciencias Ambientales, Facultad de Ciencias de la Tierra y el Mar, Universidad Nacional, Heredia, Costa Rica, pp. 95. [in Spanish]

De Camino R, Morales JP (2013). La Teca en América Latina [Teak in Latin America]. In: "Plantaciones de Teca, Mitos y Realidades" [Teak plantations, Myths and realities] (De Camino R, Morales JP eds). CATIE, Costa Rica, pp. 30-41. [in Spanish]

Díaz-Balteiro LD, Rodriguez L (2006). Optimal rotations on Eucalyptus plantations including carbon sequestration - A comparison of results in Brazil and Spain. Forest Ecology and Management 229: 247-258. - doi: 10.1016/j.foreco.20 06.04 .005

Diaz-Balteiro L, Romero C (2003). Carbon captured as a new instrument in forest management: some implications. Scientia Forestalis 63: 103-114. [online] URL: http://www.sifloresta. ufv.br/handle/123456789/17335

Dréo J, Pétrowski A, Siarry P, Taillard E (2006). Metaheuristics for hard optimization. SpringerVerlag, Berlin, Germany, pp. 369. [online] URL: http://books.google.com/books?id=l-acEfdFZ1M C

Fonseca W (2004). Manual de productores de teca (Tectona grandis L. f) en Costa Rica [Manual for teak producers in Costa Rica]. Web site. [in Spanish] [online] URL: http://www.fonafifo. com/text_files/proyectos/ManualProductoresT eca.pdf

Gera N, Gera H, Bisht NS (2011). Carbon sequestration potential of selected plantation interventions in Terai region of Uttarakhand. Indian Forester 137: 273-289. [online] URL: http:// www.indiaenvironmentportal.org.in/files/carbo nsequesteration.pdf

Hoen HF, Solberg B (1994). Potential and economic efficiency of carbon sequestration in forest biomass through silvicultural management. Forest Science 40: 429-351. [online] URL: http://www.ingentaconnect.com/content/saf/fs /1994/00000040/00000003/art00006

IPCC (2005). Orientación de buenas prácticas para uso de la tierra, cambio de uso de la tierra y silvicultura. Programa del IPCC sobre inventarios nacionales de gases de efecto invernadero [Best practices orientation for land use, land use change and silviculture. IPCC Program on greenhouse gas national inventories]. World Meteorological Organization, Geneva, Switzerland, pp. 628. [in Spanish]

Jayaraman K, Rugmini P (2008). Optimizing management of even-aged teak stands using growth simulation model: a case study in Kerala. Journal of Tropical Forest Science 20: 19-28. [online] URL: http://www.jstor.org/stable/2361 6484

Jerez M, Carrero O, Moret Y, Quevedo A, Macchiavelli R (2011). Curvas de índice de sitio basadas en modelos mixtos para plantaciones de teca (Tectona grandis L. F.) en los llanos de Venezuela [Site index curves based on mixed models for teak (Tectona grandis L. F.) plantations in the Venezuelan plains]. Agrociencia 45: 135-145. [in Spanish]

Jerez $M$, Quintero $M$, Quevedo A, Moret A (2015). Simulador de crecimiento y secuestro de carbono para plantaciones de teca en Venezuela: una aplicación en SIMILE [Growth and carbon sequestration simulator for teak plantations in Venezuela: an application in SIMILE]. Bosque 36: 519-530. [in Spanish] - doi: 10.4067/S0717-92002015000300018

Kaipanen T, Liski J, Pussinen A, Karjalainen T (2004). Managing carbon sinks by changing rotation length in European forests. Environmental. Science and Policy 7: 205-219. - doi: 10.1016/ j.envsci.2004.03.001

Keles S, Baskent EZ (2007). Modeling and analyzing timber production and carbon sequestration values of forest ecosystems: a case study. Polish Journal of Environmental Studies 16: 473479.

Keogh RM (2013). La teca y su importancia económica a nivel mundial [Teak and its economic importance at the world level]. In: "Plantaciones de Teca, Mitos y Realidades" (De Camino R, Morales JP eds). CATIE, Costa Rica, pp. 828. [in Spanish]

Kraenzel M, Castillo A, Moore T, Potvin C (2003). Carbon storage of harvest-age teak (Tectona grandis) plantations, Panamá. Forest Ecology and Management 173: 213-225. - doi: 10.1016/ S0378-1127(02)00002-6

Liski J, Pussinen A, Pingoud K, Mäkipää T, Karjalainen $T$ (2001). Which rotation is favorable for carbon sequestration? Canadian Journal of Forest Research 31: 2004-2013. - doi: 10.1139/x01140

Liu G, Han S, Zhao X, Nelson JD, Wang H, Wang W (2006). Optimisation algorithms for spatially constrained forest planning. Ecological Modelling 194: 421-428. - doi: 10.1016/j.ecolmodel.20 05.10.028

Moret AY, Jerez M, Mora A (1998). Determinación de ecuaciones de volumen para planta- ciones de teca (Tectona grandis L.) en la unidad experimental de la Reserva Forestal Caparo, Estado Barinas - Venezuela [Determining volume equations for teak plantations (Tectona grandis L.) in the experimental unit of the Caparo Forest Reserve, Barinas State - Venezuela] Revista Forestal Venezolana 42: 41-50. [in Spanish]

Nepal P, Grala RK, Grebner DL (2012). Financial feasibility of increasing carbon sequestration in harvested wood products in Mississippi. Forest Policy and Economics 20: 16-24. - doi: 10.1016/j. forpol.2012.01.011

Osorio O (1997). Regímenes de espesura y sus efectos en la rentabilidad de teca (Tectona grandis L.f) en Caparo, Venezuela [Stocking regimes and their effects in teak (Tectona grandis L. f) profitability in Caparo, Venezuela]. Universidad de Los Andes, Facultad de Ciencias Forestales y Ambientales, Centro de Estudios Forestales y Ambientales de Postgrado, Mérida, Venezuela, pp. 98. [in Spanish]

Pérez LD (2005). Stand growth scenarios for Tectona grandis plantations in Costa Rica. Academic Dissertation, University of Helsinki, Finland, pp. 77.

Pérez LD, Kanninen M (2005). Stand growth scenarios for Tectona grandis plantations in Costa Rica. Forest Ecology and Management 158: 103115. - doi: 10.1016/j.foreco.2005.02.037

Pérez S, Jand R, Rubio A (2007). Modelización del secuestro de carbono en sistemas forestales: efecto de la elección de especie [Modeling of carbon sequestration in forest systems: effect of species selection]. Ecología 21: 341-352. [in Spanish]

Pohjola J, Valsta L (2007). Carbon credits and management of Scots pine and Norway spruce stands in Finland. Forest Policy and Economics 9: 789-798. - doi: 10.1016/j.forpol.2006.03.012

Pukkala T, Kurttila M (2005). Examining the performance of six heuristic search techniques in different forest planning problems. Silva Fennica 39: 67-80. [online] URL: http://www. metsantutkimuslaitos.fi/silvafennica/full/sf39/sf 391067.pdf

Pussinen A, Karjalainen T, Mäkipää T, Valsta L, Kellomäki S (2002). Forest carbon sequestration and harvests in relation to applied rotation lengths under different climate and nitrogen deposition scenarios. Forest Ecology and Management 158: 103-115. - doi: 10.1016/S0378-1127 (00)00675-7

Quintero MA, Jerez M, Ablan M (2010). Métodos heurísticos en la planificación del manejo forestal: un ejemplo de aplicación [Heuristics methods for forest management planning]. Revista Forestal Venezolana 54:183-194. [in Spanish] Quintero MA, Jerez M, Ablan M (2011). Evaluación de tres técnicas heurísticas para resolver un modelo de planificación del aprovechamiento en plantaciones forestales industriales [Evaluating three heuristic techniques for solving a harvest planning model for industrial forest plantations]. Interciencia 36: 348-355. [in Spanish]

Quintero MA, Jerez M, Flores J (2012). Modelo de crecimiento y rendimiento para plantaciones de teca (Tectona grandis L.) usando el enfoque de espacio de estados [Growth and yield model for teak plantations (Tectona gran- 
dis L.) based on the space-state approach]. Revista Ciencia e Ingeniería 33: 33-42. [in Spanish] Raymer AK, Gobakken T, Solberg B, Hoen HF, Bergseng E (2009). A forest optimisation model including carbon flows: application to a forest in Norway. Forest Ecology and Management 258: 579-589. - doi: 10.1016/j.foreco.2009. 04.036

Zeng HC, Pukkala T, Peltola H, Kellomaki S (2007). Application of ant colony optimization for the risk management of wind damage in forest planning. Silva Fennica 41 (2): 315-332. doi: 10.14214/sf.299

Zhu J, Bettinger P (2008). Assessment of three heuristics for developing large-scale spatial forest harvest scheduling plans. Journal of Ap- plied Sciences 8: 4113-4120. - doi: 10.3923/jas.20 08.4113 .4120

\section{Supplementary Material}

Tab. S1 - Growth and yield data from Tectona grandis plantations in the Venezuelan Western Plains.

Tab. S2 - Parameter estimates for the growth and yield model.

Tab. S3 - Parameter estimates for calculating carbon storage in biomass.
Tab. S4 - Decomposition and anthropogen times for the woody biomass of teak trees (adapted from Hoen \& Solberg 1994).

Tab. S5 - Proportion of product type by diameter categories of teak trees.

Tab. S6 - Roundwood prices of teak timber from Latin American plantations (2012).

Tab. S7 - Scenarios for determining the model's sensitivity to changes in required annual production quotas for the whole project.

Link: Quintero-Mendez_1733@supploo1.pdf 